\title{
Acid-base imbalance: a review with proposed unified diagnostic algorithm
} Desequilibrio ácido-base: una revisión con el algoritmo de diagnóstico unificado propuesto

\author{
${ }^{\oplus}$ José Correa Guerrero ${ }^{1},{ }^{\oplus}$ Jorge Rico Fontalvo $2,{ }^{\oplus}$ Rodrigo Daza Arnedo ${ }^{3},{ }^{\bullet}$ Emilio Abuabara Franco $^{4}$,

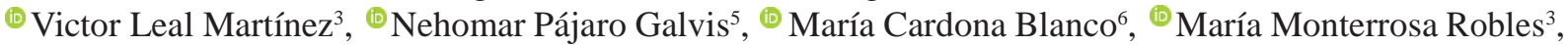 \\ ${ }^{\oplus}$ Jenniffer Palomino Herrera ${ }^{5}$, ${ }^{\circ}$ Mauricio Batista Lambis ${ }^{5}$, ${ }^{\oplus}$ Isaias Garcerant Campo $^{7}$, \\ ${ }^{\circ}$ Ronald Castro Ahumada ${ }^{7}{ }^{\odot}$ Karen Perales Caballero ${ }^{7}$

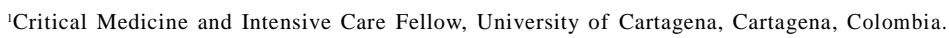 \\ ${ }^{2}$ SOMA Clinic, Medellín, Colombia. \\ ${ }^{3}$ New Bocagrande Hospital, Cartagena, Colombia. \\ ${ }^{4}$ ESTRIOS Clinic, Cartagena, Colombia. \\ ${ }^{5}$ University of Sinu, Cartagena, Colombia. \\ ${ }^{6}$ Renal Unit B. Braun, Medellín, Colombia.. \\ ${ }^{7}$ CARI Hospital, Barraquilla, Colombia.
}

\begin{abstract}
Introduction: Alterations in the acid-base balance are studied in all medical specialties. Although most cases derive from a preexisting pathology, they can also manifest themselves in a primary context. The proper identification of the acid-base disorder allows the pathological process to be characterized. The correct interpretation of the blood gasometry as a technique for monitoring the ventilatory status, oxygenation and acid-base balance of a patient requires the integration of various physicochemical approaches in order to specify a diagnosis, quantify a therapeutic response, and monitor the severity or the progression of a pathological process. Methodology: A literature review was conducted in the PubMed, Scopus and Science Direct databases. The articles were selected according to the title and the abstract and sorted by topics relevant by pathophysiology, divergences, clinical approach, diagnosis, and management.

Results: A guide the clinical correlation of the critical patient with the blood gasometry parameters to characterize the acid-base disorder through the proposition of a diagnostic algorithm.

Conclusion: The incorporation of the three theories in a diagnostic algorithm facilitates a greater understanding of the pathophysiological mechanisms and allows us to identify a more precise therapeutic objective to correct the underlying disorder in the different clinical contexts of the patient.
\end{abstract}

Keywords: Acid-base imbalance, blood gas analysis, diagnosis, algorithms (MeSH)

doi:http://dx.doi.org/10.22265/acnef.7.2.497

\section{Resumen}

Introducción: las alteraciones del equilibrio ácido-base se estudian en todas las especialidades médicas. Aunque la mayoría de los casos derivan de una patología preexistente, también pueden manifestarse en un contexto primario, por lo que la identificación adecuada del trastorno ácido-base permite caracterizar su proceso patológico. La correcta interpretación de la gasometría sanguínea como técnica para monitorizar el estado ventilatorio, la oxigenación y el equilibrio ácido-base de un paciente requiere la integración de varios enfoques fisicoquímicos para precisar un diagnóstico, cuantificar una respuesta terapéutica y monitorizar la gravedad o la progresión de un proceso patológico.

Materiales y métodos: se realizó una revisión de la literatura en las bases de datos PubMed, Scopus y ScienceDirect. Los artículos fueron seleccionados según el título y el resumen, y ordenados por tópicos relevantes por fisiopatología, divergencias, abordaje clínico, diagnóstico y manejo.

Resultados: en la literatura consultada se evidenció que el uso de un enfoque lógico y sistemático es necesario para interpretar adecuadamente los parámetros de la gasometría sanguínea e identificar oportunamente el trastorno ácido-base.

Conclusión: la incorporación de las tres teorías en un algoritmo diagnóstico facilita una mayor comprensión de los mecanismos fisiopatológicos y permite identificar un objetivo terapéutico más preciso para corregir el trastorno de base en los diferentes contextos clínicos del paciente.

Palabras clave: desequilibrio ácido-base, análisis de los gases de la sangre, diagnóstico, algoritmos.

doi:http://dx.doi.org/10.22265/acnef.7.2.497

Citation: Correa Guerrero J, Rico Fontalvo J, Daza Arnedo R, Abuabara-Franco E, Leal-Martínez V, Pájaro Galvis N. Acid-base imbalance: a review with proposed unified diagnostic algorithm. Rev. Colomb. Nefrol. 2020;7(2):85-97. https://doi.org/10.22265/acnef.7.2.497

Received: 27.07.19, Accepted: 04.08.20, Online: 04.08.20

Correspondence: Nehomar Pajaro Galvis, neho94@hotmail.com

Correa Guerrero J, Rico Fontalvo J, Daza Arnedo R, 


\section{Introduction}

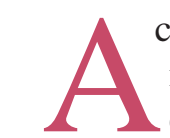

cid-base disorders are frequent, especially in the critical patient. Although most of the cases derive from a preexisting pathology, they can also manifest themselves in a primary context. ${ }^{1,2}$ The proper identification of the acid-base disorder allows to characterize the causative pathological process. ${ }^{1-4}$ Classically, different authors: Siggard, Andersen, Henderson, Emmett, Hasselbalch and Stewart have contributed to the understanding of the acid-base balance. ${ }^{3-6}$ In clinical practice, three models are currently used: (A) The HendersonHasselbalch equation to classify the acid-base disorders. ${ }^{6}$ (B) The base excess concept by SiggaardAndersen $^{7}$ as a parameter to assess the magnitude of the metabolic abnormality. ${ }^{6}(\mathrm{C})$ The strong ion difference proposed by Stewart, ${ }^{89}$ which offers more information about extreme acid-base conditions observed in the critical patient. ${ }^{4}$ The correct interpretation of the blood gasometry requires the integration of the above mentioned three models in order to specify a diagnosis, quantify a therapeutic response and monitor the severity or the progression of a pathological process..$^{3-5}$ The aim of this article is to originally propose a diagnostic algorithm for guiding physicians to perform an adequate correlation between the clinical condition of critical patients and their acidbase parameters, in order to achieve an accurate characterization of the patients' acid-base disorders.

\section{Material \& Method}

A review of the literature was performed in the PubMed, Scopus and Science Direct databases. The following MESH terms were used for the advanced search, such as "acid-base equilibrium" or "acid-base imbalance" or "acidosis "or " alkalosis", which were included in the articles title, abstract or key words. The search was restricted to articles published after 2000, although some previous articles were reviewed in order to describe traditional approaches. The articles were selected according to the title and the abstract and sorted by topics considered relevant by the authors for performing a detailed review, including pathophysiology, divergences, clinical approach (according to different authors), diagnosis, and management.

\section{Blood gasometry}

The blood gasometric study is indicated when there is the need to evaluate the ventilatory status, the oxygenation and the acid-base balance in order to establish a diagnosis, measure the therapeutic response to oxygen-therapy and monitor the severity of a pathological process. ${ }^{10}$ The blood gas analyzers use three types of electrodes for the direct measurement of the hydrogen-ion potential $(\mathrm{pH})$, the partial pressure of oxygen $\left(\mathrm{pO}_{2}\right)$ and the partial pressure of carbon dioxide $\left(\mathrm{pCO}_{2}\right)$, from these measurements it is possible to mathematically calculate other parameters such as the bicarbonate ion $\left(\mathrm{HCO}_{3}^{-}\right)$, the base excess (BE), and the oxygen saturation $\left(\mathrm{SaO}_{2}\right)($ Table 1$){ }^{6,11,12}$

\section{Importance of $\mathrm{pH}$ regulation}

The hydrogen-ion $\left(\mathrm{H}^{+}\right)$is one of the most important parameters in the acid-base balance and its concentration depends on the interaction between the $\mathrm{pCO}_{2}$, the plasma concentration of $\mathrm{HCO}_{3}$ - and the dissociation constant of $\mathrm{H}_{2} \mathrm{CO}_{3}{ }^{12-14}$ The $\mathrm{pH}$ at physiological levels is essential for biological processes, including the supply of oxygen to the tissues, the correct structure of the proteins and countless biochemical reactions that depend on a neutral $\mathrm{pH}$ to be in equilibrium. ${ }^{12,15,16} \mathrm{In}$ addition, cell functions such as glycolysis, gluconeogenesis, mitosis, DNA synthesis, among others, are altered by acute changes in $\mathrm{pH}$. Therefore, a series of compensatory mechanisms is required to respond quickly to the changes in the concentration of $\mathrm{H}^{+}$in all cellular compartments. ${ }^{12,16,17}$

\section{Compensation systems}

The concentration of $\mathrm{H}^{+}$within the plasma and other aqueous solutions is tightly regulated. The cell metabolism produces about $70 \mathrm{mmol} / \mathrm{day}$ of $\mathrm{H}^{+}$, but under physiological conditions, the concentration remains balanced between $36-43 \mathrm{nmol} / \mathrm{L},{ }^{,, 17}$ due to the following regulation systems:

Buffering: It is a rapid physicochemical response. A buffer is a solution that resists the changes in $\mathrm{pH}$ when acids or alkalis are added. The buffers that regulate the $\mathrm{pH}$ in intracellular and extracellular fluids 
Table 1. Normal serum parameters

\begin{tabular}{|c|c|}
\hline Parameter & Normal Value \\
\hline $\mathrm{pH}$ & $7.35-7.45$ \\
\hline $\mathrm{pCO}_{2}(\mathrm{mmHg})$ & $35-45$ \\
\hline $\mathrm{HCO}_{3}{ }^{-}(\mathrm{mmol} / \mathrm{L})$ & $20-24$ \\
\hline $\mathrm{pO}_{2}(\mathrm{mmHg})$ & $80-100$ \\
\hline $\mathrm{SaO}_{2}(\%)$ & $95-100$ \\
\hline $\mathrm{BE}$ & -2 to +2 \\
\hline $\mathrm{Lactate}^{(\mathrm{mmol} / \mathrm{L})}$ & $<2$ \\
\hline $\mathrm{Na}^{+}(\mathrm{mEq} / \mathrm{L})$ & $135-145$ \\
\hline $\mathrm{K}^{+}(\mathrm{mEq} / \mathrm{L})$ & $3.5-5.5$ \\
\hline $\mathrm{Cl}^{-}(\mathrm{mEq} / \mathrm{L})$ & $95-105$ \\
\hline
\end{tabular}

$\mathrm{pH}$ : hydrogen-ion potential; $\mathrm{pCO}_{2}:$ partial pressure of carbon dioxide; $\mathrm{HCO}_{3}{ }^{-}$: bicarbonate ion; $\mathrm{pO}_{2}$ : partial pressure of oxygen; $\mathrm{SaO}_{2}$ : arterial oxygen saturation; $\mathrm{BE}$ : base excess; $\mathrm{Na}^{+}$: sodium ion, $\mathrm{K}^{+}$: potassium ion, $\mathrm{Cl}$ : chloride ion. Source: own elaboration.

include sodium bicarbonate $\left(\mathrm{NaHCO}_{3}\right)$, carbonic acid $\left(\mathrm{H}_{2} \mathrm{CO}_{3}\right)$, phosphates, proteins (albumin, globulins), hemoglobin and oxyhemoglobin. ${ }^{12,16-18}$ The dynamics of the system is predominantly of $\mathrm{HCO}_{3}-/ \mathrm{H}_{2} \mathrm{CO}_{3}$ as follows:

$$
\mathrm{CO}_{2}+\mathrm{H}_{2} \mathrm{O} \leftrightarrow \mathrm{H}_{2} \mathrm{CO}_{3} \leftrightarrow \mathrm{H}^{+}+\mathrm{HCO}_{3}+\left(\mathrm{Na}^{+}\right) \leftrightarrow \mathrm{NaHCO}_{3}
$$

Le Chatelier principle establishes that when the concentration, pressure or temperature variables change, the systems in equilibrium react accordingly to reestablish a new equilibrium state, which indicates that if more $\mathrm{H}^{+}$are produced, the equation will shift to the left so that more reagents are formed and the system remains in equilibrium. ${ }^{12,17}$ The conversion of $\mathrm{CO}_{2}$ into $\mathrm{H}_{2} \mathrm{CO}_{3}$ is slowly catalyzed by the carbonic anhydrase present in the pulmonary and renal tissues. The $\mathrm{H}_{2} \mathrm{CO}_{3}$ is slowly ionized to produce $\mathrm{H}^{+}$and $\mathrm{HCO}_{3}$, while the $\mathrm{NaHCO}_{3}$ is completely ionized to produce $\mathrm{HCO}_{3-}{ }^{-4,5,14}$

The respiratory system, increases or reduces the concentration of $\mathrm{H}+$ or $\mathrm{CO} 2$, through changes in alveolar ventilation (hypoventilation or hyperventilation, respectively) mediated by chemoreceptors. From the quantitative point of view, it is the predominant system and depends on the complete oxidation of the anions during the Krebs cycle..$^{3,16,19,20}$

The renal system, eliminates the $\mathrm{H}^{+}$produced in the amino acids metabolism, through the formation of urea or ammonium ion, at the same time that the secretion of $\mathrm{H}^{+}$in the proximal tubule increases or decreases; in addition, it reabsorbs around $80 \%$ of the $\mathrm{HCO}_{3}{ }^{-}$. There is an important relationship between the transport of $\mathrm{HCO}_{3}$ - and the excretion of acid because during acidosis, the excretion of titratable acid (phosphate buffer) is modified inversely with the administered amount of $\mathrm{HCO}_{3}$ - . The distal acidification is constituted not only by the titratable acidity, but fundamentally by the ammoniacal acidity, which is regulable as it can be induced by aldosterone. ${ }^{3,12,13,18,21}$

Therefore, the acid-base balance disorders will have a compensatory response: renal, mediated by $\mathrm{HCO}_{3}$ - in respiratory disorders, and respiratory, mediated by $\mathrm{CO}_{2}$ in metabolic disorders (Table 2).

In addition, acid base disorders can be characterized according to the increase or decrease of the $\mathrm{pH} /$ $\mathrm{HCO}_{3}-/ \mathrm{pCO}_{2}$ variables in order to identify the evolution

Correa Guerrero J, Rico Fontalvo J, Daza Arnedo R, 
Table 2. Primary disorders and expected compensations

\begin{tabular}{|l|c|c|c|c|c|}
\hline Primary disorder & $\mathbf{p H}$ & $\mathbf{p C O 2}$ & $\mathrm{HCO}_{3}^{-}$ & \multicolumn{2}{|c|}{ Compensatory change } \\
\hline Respiratory acidosis & $<7.35$ & $>45$ & - & $\mathrm{HCO}_{3}^{-}$ & $\mathbf{4}$ \\
\hline Metabolic acidosis & $<7.35$ & - & $<20$ & $\mathrm{pCO}_{2}$ & $\downarrow$ \\
\hline Respiratory alkalosis & $>7.45$ & $<35$ & - & $\mathrm{HCO}_{3}^{-}$ & $\downarrow$ \\
\hline Metabolic alkalosis & $>7.45$ & & $>24$ & $\mathrm{pCO}_{2}$ & $\mathbf{4}$ \\
\hline
\end{tabular}

pH: hydrogen-ion potential; $\mathrm{pCO} 2$ : partial pressure of carbon dioxide; $\mathrm{HCO}_{3-}$ : bicarbonate ion

Source: own elaboration.

time as acute, subacute and chronic. (i.e., if a metabolic alkalosis have increased $\mathrm{pH}, \mathrm{HCO}_{3^{-}}$and $\mathrm{pCO}_{2}$ it indicates a subacute metabolic alkalosis) (Table 3). ${ }^{4,6,16}$

In the table 4, useful formulas are provided for acidbase interpretation that allow to calculate the compensatory response of the renal and respiratory systems. (i.e., if a metabolic acidosis produces $\mathrm{HCO}_{3}$ - of $15 \mathrm{mEq} / \mathrm{L}$, the expected $\mathrm{pCO}_{2}$ is $\left.(1.5 \times 15+8) \pm 2=30.5 \pm 2 \mathrm{mmHg}\right)$. If the measured $\mathrm{pCO}_{2}$ is equivalent to the expected $\mathrm{pCO}_{2}$, the respiratory compensation is adequate and the condition is called compensated metabolic acidosis. . $^{12,1822}$

\section{Acid-Base Interpretation Models}

\section{(A) Henderson-Hasselbalch equation}

The traditional Henderson-Hasselbalch approach defines the $\mathrm{pH}$ in its non-logarithmic variant as $\left[\mathrm{H}^{+}\right]=$ $24+\mathrm{pCO}_{2} / \mathrm{HCO}_{3^{-}}$. The model is based on the application of the mass action law in equilibrium of $\mathrm{CO}_{2}$ and the existing relationship between the plasma $\mathrm{HCO}_{3-}$ and the concentration of strong acids, ${ }^{20,23}$ through the following formula:

$$
\mathbf{p H}=\mathrm{pKa}+\log _{10}\left[\mathrm{HCO}_{3^{-}}\right] /\left(0.03 \times \mathrm{pCO}_{2}\right)
$$

Table 3. Evolution of acid-base disorders

\begin{tabular}{|c|c|c|c|c|}
\hline Disorder & Status & pH & $\mathrm{pCO}_{2}$ & $\mathrm{HCO}_{3}$ \\
\hline \multirow{3}{*}{ Respiratory acidosis } & Acute & $\downarrow$ & 4 & - \\
\hline & Subacute & $\downarrow$ & 4 & 4 \\
\hline & Chronic & - & 4 & 4 \\
\hline \multirow{3}{*}{ Metabolic acidosis } & Acute & $\downarrow$ & - & $\downarrow$ \\
\hline & Subacute & $\downarrow$ & $\downarrow$ & $\downarrow$ \\
\hline & Chronic & - & $\downarrow$ & $\downarrow$ \\
\hline \multirow{3}{*}{ Respiratory alkalosis } & Acute & 4 & $\downarrow$ & - \\
\hline & Subacute & 4 & $\downarrow$ & $\downarrow$ \\
\hline & Chronic & - & $\downarrow$ & $\downarrow$ \\
\hline \multirow{3}{*}{ Metabolic alkalosis } & Acute & 4 & - & 4 \\
\hline & Subacute & 4 & 4 & 4 \\
\hline & Chronic & - & 4 & 4 \\
\hline
\end{tabular}

pCO2: partial pressure of carbon dioxide; $\mathrm{HCO}_{3-}$ : bicarbonate ion 
Table 4. Primary disorders and compensatory responses

\begin{tabular}{|l|l|}
\hline Primary Disorder & Expected result \\
\hline Metabolic acidosis & Expected $\mathrm{pCO}_{2}=\left(1.5 \mathrm{x} \mathrm{HCO}_{3}{ }^{-}+8\right) \pm 2$ \\
\hline Metabolic alkalosis & Expected $\mathrm{pCO}_{2}=\left(0.7 \times \mathrm{HCO}_{3}{ }^{-}+23\right) \pm 2$ \\
\hline Acute respiratory acidosis & Expected $\mathrm{HCO}_{3}{ }^{-}=24+0.1 \times\left(\mathrm{pCO}_{2}-40\right)$ \\
\hline Chronic respiratory acidosis & Expected $\mathrm{HCO}_{3}{ }^{-}=24+0.4 \times\left(\mathrm{pCO}_{2}-40\right)$ \\
\hline Acute respiratory alkalosis & Expected $\mathrm{HCO}_{3}^{-}=24-0.2 \times\left(40-\mathrm{pCO}_{2}\right)$ \\
\hline Chronic respiratory alkalosis & Expected $\mathrm{HCO}_{3}^{-}=24-0.5 \times\left(40-\mathrm{pCO}_{2}\right)$ \\
\hline
\end{tabular}

pCO2: partial pressure of carbon dioxide; HCO3- : bicarbonate ion

In this equation, $\mathrm{pKa}$ is the negative logarithm of the acid dissociation constant of the weak acid. The equation allows to infer that the $\mathrm{CO}_{2}$ and the $\mathrm{HCO}_{3}$ are variables that determine the system that corrects the alterations of the $\mathrm{H}^{+}$, which allows to classify the acid-base disorders according to the primary type of acid that is increased or decreased. ${ }^{16,24}$

Although it is mathematically accurate, it does not consider aspects such as the presence of buffers other than $\mathrm{HCO}_{3}$ - (plasma proteins), the intervention of weak acids such as phosphates and the directly proportional correlation that exists between $\mathrm{HCO}_{3}$ - and $\mathrm{pCO}_{2} \cdot{ }^{8,22,24}$

Metabolic acidosis can be induced by two main mechanisms: bicarbonate consumption secondary to buffer activity, or body bicarbonate loss. Both conditions can be distinguished by evaluating the patient's anion gap (AG) value.

\section{Acid-base imbalance: a review with proposed unified diagnostic algorithm}

\section{Running head: acid-base imbalance}

\section{Anion gap}

The AG is the difference between plasma anions and cations, based on the electroneutrality principle. The resulting value is usually positive $(12 \pm 2 \mathrm{mEq} / \mathrm{l})$, and reflects anions such as proteins, phosphates and sulfates. ${ }^{20,23,25}$
The mnemonic to remember the causes of metabolic acidosis with increased AG is "MUDPILES": Methanol, Uremia, Diabetic ketoacidosis (DKA), Paraldehyde, Isoniazid and Iron, Lactic acid, Ethylene glycol and Ethanol induced ketoacidosis, Salicylates. It is used to establish the differential diagnosis of the metabolic acidosis because it allows to distinguish the causes. ${ }^{5,25}$ For the metabolic acidosis with normal AG is used the mnemonic

“ACCRUED": Aldosterone inhibitors, Compensation for respiratory alkalosis, Carbonic anhydrase inhibitors (acetazolamide), Renal tubular acidosis (RTA), Ureteral diversion, Extra alimentation and Diarrhea ${ }^{4}$. Regarding the limitations of the AG, they include: assumption of normal concentrations of albumin and phosphates, exclusion of unmeasured ions, therefore, in the critical patient ${ }^{26}$ the corrected AG must be used:

$\left(\mathrm{Na}^{+}+\mathrm{K}^{+}\right)-\left(\mathrm{Cl}^{-}+\mathrm{HCO}_{3}^{-}\right)+2.5$ (Normal albumin - Measured albumin)

A corrected AG value above 12 indicates metabolic acidosis with increased AG, and a corrected AG value under 12 indicates metabolic acidosis with normaldecreased AG. There may be situations where concurrent metabolic disorders exist. To identify if mixed metabolic disorders are present, the delta Gap should be calculated $(\nabla G a p=$ Corrected AG - Calculated AG). An AG delta $>6$ is a metabolic acidosis with increased $A G$ and an AG delta $<6$ is a metabolic acidosis with normal AG. When there is a suspicion that the origin of

Correa Guerrero J, Rico Fontalvo J, Daza Arnedo R, Abuabara-Franco E, Leal-Martínez V, Pájaro Galvis N. 
the metabolic acidosis is a toxic agent, it will be indispensable to calculate the osmolar gap (OG) by applying the following equation. ${ }^{4,5,25}$

$$
\begin{aligned}
\mathrm{OG}= & \text { measured serum osmolarity }- \text { calculated } \\
& \text { serum osmolarity }
\end{aligned}
$$

In a case of increased AG metabolic acidosis secondary to intoxication, the OG value would be higher than 10. In case of a normal AG metabolic acidosis, the urinary AG should be obtained by applying the following equation: ${ }^{5,25}$

$$
\begin{aligned}
\text { Urinary AG }= & (\text { urinary sodium }+ \text { urinary potassium }) \\
& - \text { urinary chloride }
\end{aligned}
$$

A positive urinary AG value (>20) suggests a normal AG metabolic acidosis secondary to distal renal tubular acidosis, while a negative urinary AG value $(<-20)$ suggests a normal AG metabolic acidosis secondary to proximal tubular acidosis or bicarbonate loss due to diarrhea.

\section{(B) Base Excess}

In order to understand how the $\mathrm{pH}$ and the concentration of $\mathrm{HCO}_{3}$ - are altered independently of the $\mathrm{pCO}_{2}$, Siggard-Andersen proposed the concept of base excess (BE) as the amount of acid-base or strong base required to maintain the $\mathrm{pH}$ in 7.4 and a temperature of $37{ }^{\circ} \mathrm{C}$ with a $\mathrm{pCO}_{2}$ of $40 \mathrm{mmHg} \cdot{ }^{3,15,25-27}$. The $\mathrm{BE}$ normal value is -2 to +2 . The $\mathrm{BE}$ limitation is that it does not allow to determine the metabolic acidosis cause and assumes that patient's serum albumin and phosphate levels are normal. Since serum albumin and phosphate levels in the critical patient are frequently decreased, thus the corrected BE equation should be used. ${ }^{27}$

$$
\begin{aligned}
& \mathrm{BE}=\left(\mathrm{HCO}_{3^{-}}-24.4\right)+(8.3 \times \text { albumin } \mathrm{x} 0.15)+ \\
& (0.29 \times \text { phosphate } \mathrm{x} 0.32) \times(\mathrm{pH}-7.4)
\end{aligned}
$$

\section{(C) Peter-Stewart model}

The Stewart model $^{7}$ includes the analysis and the relationship of the components of human fluids (water, strong ions in water, weak acids in water and $\mathrm{CO}_{2}$ ) through the following fundamental physicochemical principles: electroneutrality principle, conservation of mass law, and equilibrium of electrochemical dissociation. In addition, it adds the $\mathrm{HCO}_{3}$ as a dependent variable, establishing that the changes in the $\mathrm{H}^{+}$and therefore, in the $\mathrm{pH}$, can only occur through the modification of three independent factors: (i) $\mathrm{pCO}_{2}$, (ii) strong ion difference (SID) and (iii) total weak acid concentration $\left(\mathrm{A}_{\mathrm{TOT}}\right)$. $^{2,7,9,22}$ (i) The $\mathrm{pCO}_{2}$ is defined as the pressure exerted by the $\mathrm{CO}_{2}$ in the arterial blood, independently from each arterial gas. (ii) The SID is the difference between the sum of the plasma concentrations of cations and anions; the normal value is 36 to $40 \mathrm{mEq} / \mathrm{L}$ and it has a great electrochemical value on the dissociation of water: as the SID increases, the $\mathrm{H}+$ decreases and consequently the $\mathrm{pH}$ increases to balance the electroneutrality. (iii) $\mathrm{A}_{\mathrm{TO}}$ : body fluid compartments have varying concentrations of nonvolatile weak acids. The most important weak acids in plasma are proteins and phosphates. The same applies to interstitial fluid, although total concentrations here are very small. In red cells the predominant source is hemoglobin..$^{28}$

The $\mathrm{A}_{\text {тот }}$ represents the total amount of weak acids other than $\mathrm{CO}_{2}$ in plasma. Albumin (normal value: 3.5 to $5 \mathrm{~g} / \mathrm{dl}$ ) is the most important protein that acts as a weak acid. Organic phosphates (normal value: 2.5 to 4 $\mathrm{mg} / \mathrm{dl}$ ) represent 5\% when their levels are normal. Therefore, albumin concentrations can be used to estimate plasma $\mathrm{A}_{\text {тот. }}{ }^{2,29,30}$

The non-dissociated acids are described as [HA] and the dissociated acids as $\left[\mathrm{A}^{-}\right]$. Then the weak acid dissociation reaction is:

$$
\mathrm{HA} \leftrightarrow \mathrm{H}^{+}+\mathrm{A}^{-}
$$

Based on the law of conservation of matter, if HA and $\mathrm{A}^{-}$do not participate in other reactions in the solution, the sum of $[\mathrm{HA}]$ and $\left[\mathrm{A}^{-}\right]$will remain constant, then:

$$
\left[\mathrm{A}_{\mathrm{TOT}}\right]=[\mathrm{HA}]+\left[\mathrm{A}^{-}\right]
$$

Although [ $\left[\mathrm{A}^{-}\right]$varies with $\mathrm{pH}, \mathrm{A}_{\text {тот }}$ does not, and as such it is an independent variable..$^{28,29}$

From Peter-Stewart model, it can be concluded that the $\mathrm{pH}$ variations depend on the degree of dissociation of the plasma water $\left(\mathrm{H}^{+}, \mathrm{OH}^{-}\right)$as a source for $\mathrm{H}^{+}$ 
production and in turn, this dissociation depends on the three independent factors $\left(\mathrm{pCO}_{2}, \mathrm{SID}\right.$, and $\left.\mathrm{A}_{\text {Tот }}\right) .^{30,31}$

\section{Clinical application: Diagnosis of the acid-base disorders in 7 steps}

The approach to the acid-base disorders, requires to establish a clinical correlation between the medical record of the patient (anamnesis and physical examination) and the gasometric parameters. ${ }^{3,14}$ In this review, we recommend the use of a systematic approach to problem solving through a diagnostic algorithm (Figure 1 and Figure 1.1), in order to guide the correct interpretation and the diagnosis of the acidbase disorders through the following analytical sequence:
Step 1. Identify the type of gas: the correct reading of the blood gasometry requires the verification of the arterial gas, through the ratio between the formula ( 80 Mantissa $\mathrm{pH}$ ) and the calculation of hydrogen ions $\left(\mathrm{H}^{+}=24\left(\mathrm{pCO}_{2}\right) / \mathrm{HCO}_{3}-\right)$, where the mantissa refers to the decimal fraction of a logarithm that follows the characteristic or whole part (example. 7.34, the whole part is 7 and the mantissa is 0.34 ). If the result is $<2$, then we confirm arterial gas and the analytical sequence is continued.

Step 2. Degree of Oxygenation: the $\mathrm{Pa} / \mathrm{Fi}$ index, which relates the arterial oxygen pressure and the fraction of inspired oxygen $\left(\mathrm{pO}_{2} / \mathrm{FiO}_{2}\right)$ is assessed, the alteration in gas exchange is measured as mild (200$300)$, moderate $(<200->100)$ and severe $(<100)$ respiratory distress. The $\mathbf{P a} / \mathbf{F i}$ index allows the non-
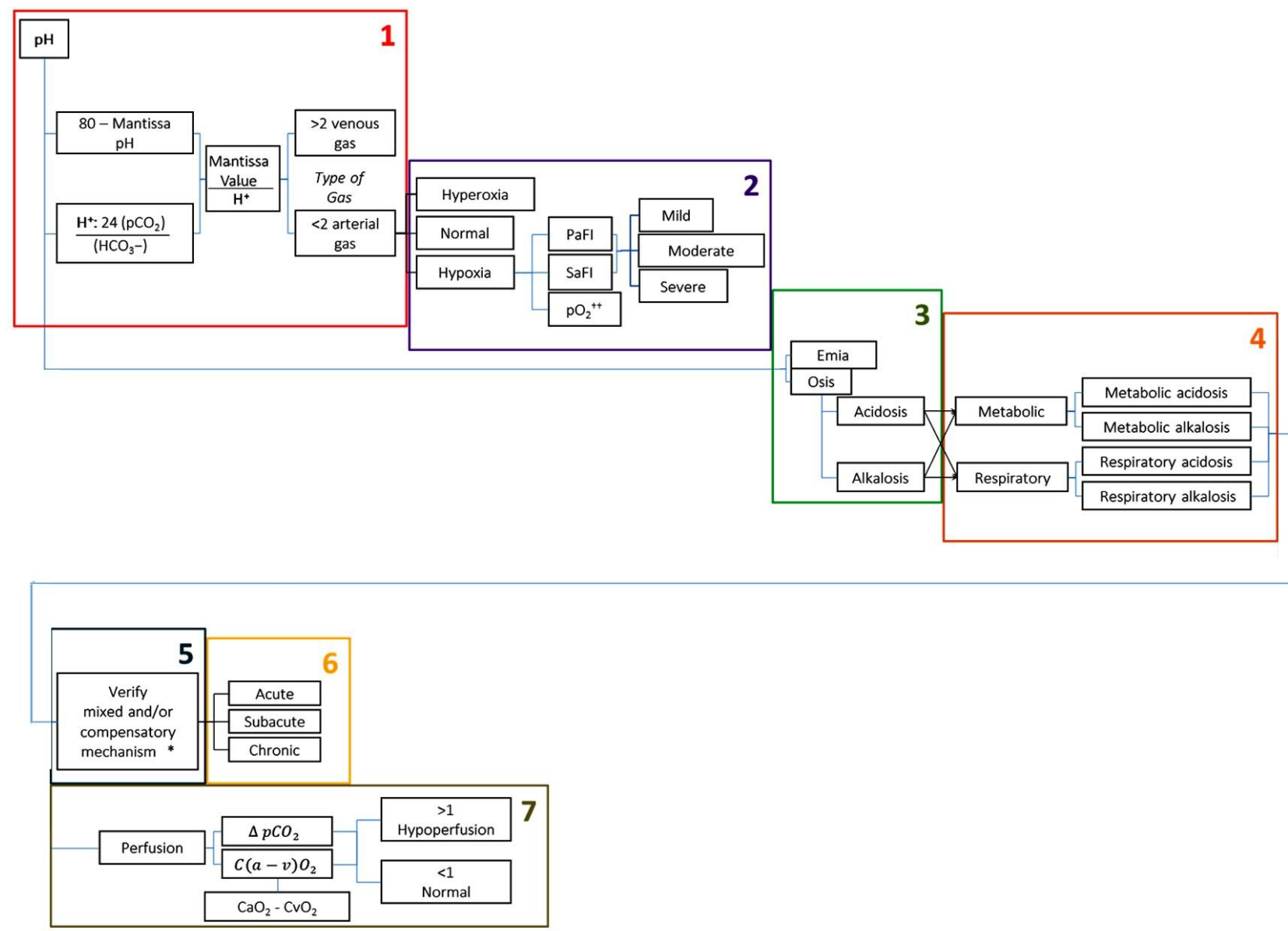

${ }^{\dagger \dagger}$ Currently in disuse $\quad$ pH: hydrogen-ion potential; pCO2: partial pressure of carbon dioxide; HCO3-: bicarbonate ion; pO2: partial pressure of oxygen; * See Table \#4 $\mathrm{CaO}_{2}$ : arterial oxygen content; $\mathrm{CvO}_{2}$ : venous oxygen content; $C(a-v) O 2$ : arteriovenous oxygen content difference.

Figure 1. Diagnostic algorithm proposal for acid-base disorders. Source: own elaboration. 


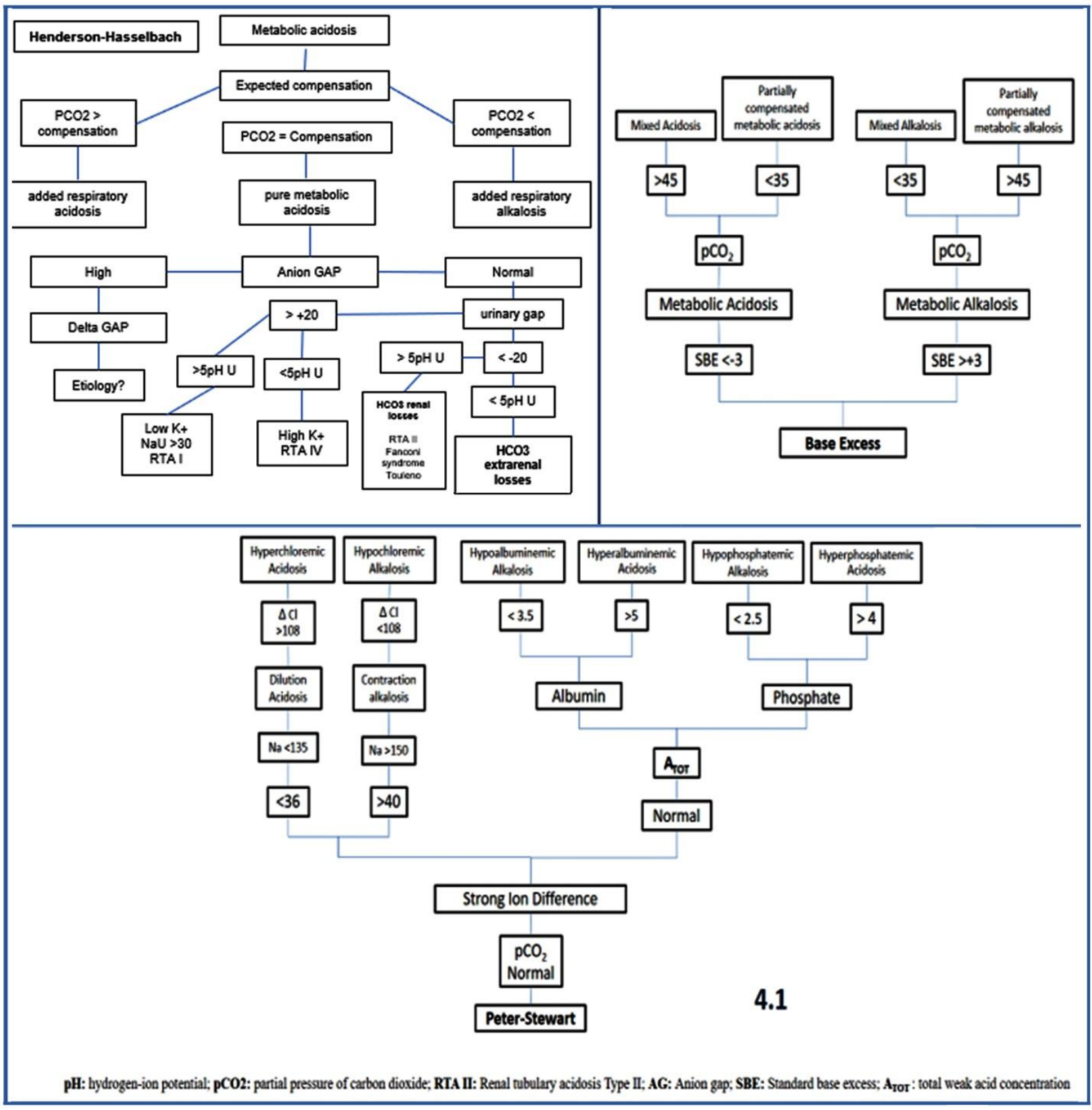

Figure 1.1. The three theories to assess acid-base imbalance. Source: own elaboration.

invasive monitoring of the oxygenation without requiring a gasometric study.

Step 3. Evaluate the $\mathrm{pH}$ status: determine if the blood $\mathrm{pH}$ indicates acidosis $(<7.35)$, alkalosis $(>7.45)$ or if it is within the normal range (7.35-7.45). The suffix "emia" is used when the $\mathrm{pH}$ is outside the normal range and "osis" when there is an acid-base alteration in which the $\mathrm{pH}$ is within the normal range.

Step 4. Characterize the primary disorder, which is the component that can explain the $\mathrm{pH}$ value: through the analysis of the metabolic $\left(\mathrm{HCO}_{3^{-}}\right)$or respiratory $\left(\mathrm{pCO}_{2}\right)$ component, in order to determine 
the origin or the predominance of the acid-base disorder (Table 2).

Step 4.1. If the disorder is metabolic, the three theories (Henderson-Hasselbalch, base excess and Peter-Stewart) should be applied in order to establish the differential diagnosis, assess the magnitude of the alteration and characterize the metabolic disorder (see Figure 1.1).

Step 5.Determine the compensatory response or the mixed disorder: subsequent to the identification of the primary disorder (metabolic or respiratory), it should be verified if the other component makes the compensation of the $\mathrm{pH}$ or if actually adds some other acidbase disorder. If both the measurement of the $\mathrm{pH}$ and the $\mathrm{pCO}_{2}$ are abnormal it is considered a mixed acidbase disorder (Table 2 and Table 4).

Step 6.Calculate gap delta. This provides very important information for the diagnosis of mixed disorders. it is calculated with the following formula (real $\mathrm{AG}$ - ideal $\mathrm{AG}$ ) / ideal $\mathrm{HCO}_{3}$ - real $\mathrm{HCO}_{3}$ ). values less than 0.4 correspond to hyperchloremic acidemia. between 0.5 and 1 to pure metabolic acidosis, 1.1 to 1.5 is equivalent to lactic acidosis and greater than 1.6 explains an over-added metabolic alkalosis.

Step 7. Identify the evolution of the disorder: through the increase or decrease of the $\mathrm{pH} / \mathrm{HCO}_{3}$ - $/$ $\mathrm{pCO}_{2}$ variables it is possible to determine the time of evolution of the acid-base disorder as acute, subacute and chronic (Table 3)

Step 8.Evaluate the perfusion: the ratio between the $\mathrm{CO}_{2}$ delta (arterial $\mathrm{CO}_{2}$ - venous $\mathrm{CO}_{2}$ ) and the arteriovenous oxygen content difference, $\mathrm{C}(\mathrm{a}-\mathrm{v}) \mathrm{O}_{2}$ (arterial oxygen content, $\mathrm{CaO}_{2}$, and venous oxygen content, $\left.\mathrm{CvO}_{2}\right)$. The $\mathrm{C}(\mathrm{a}-\mathrm{v}) \mathrm{O}_{2}$ depends on the $\mathrm{SaO}_{2}$, the $\mathrm{SvO}_{2}$ and the hemoglobin, $1 \mathrm{~g}$ of hemoglobin transports $1.34 \mathrm{~mL}$ of $\mathrm{O}_{2} \cdot 3,7,16,18,29,30,32-38$

\section{Illustrative Case}

Below, the diagnostic algorithm for the diagnosis of the acid-base disorders proposed in Figure 1 is applied to the following clinical case:
Clinical Case: A 52-year-old female is admitted to the ICU, with a history of high blood pressure, type II diabetes mellitus, heart failure with left ventricular ejection fraction of $35 \%$, the patient underwent a surgical intervention consisting of an open cholecystectomy, and in the first postoperative day she presented signs of hemodynamic instability associated with anemia requiring a new intervention due to bleeding of the gallbladder bed. Two days later, she presented fever, tachycardia, tachypnea, disorientation, and a decrease in diastolic blood pressure with requirement of oxygen with $\mathrm{FiO}_{2}$ : 0.5 . The presumptive diagnosis was a septic shock with tissue hypoperfusion, associated with subphrenic abscess. The following are the laboratory parameters:

\section{Arterial Gases}

pH: 7.17

$\mathrm{pCO}_{2}: 25 \mathrm{mmHg}$

$\mathrm{pO}_{2}: 84 \mathrm{mmHg}$

$\mathrm{HCO}_{3}{ }^{-}: 11 \mathrm{mEq} / \mathrm{L}$

$\mathrm{SaO}_{2}: 78 \%$

BE: - 14

\section{Venous Gases}

$\mathrm{pH}: 7.1$

$\mathrm{pCO}_{2}: 26 \mathrm{mmHg}$

$\mathrm{pO}_{2}: 70 \mathrm{mmHg}$

$\mathrm{HCO}_{3}{ }^{-}: 18 \mathrm{mEq} / \mathrm{L}$

$\mathrm{SvO}_{2}=72 \%$

BE: -16

\section{Chemical Panel}

$\mathrm{Na}^{+}: 135 \mathrm{mEq} / \mathrm{L}$

$\mathrm{K}^{+}: 3.5 \mathrm{mEq} / \mathrm{L}$

$\mathrm{Cl}^{-}: 100 \mathrm{mEq} / \mathrm{L}$

$P: 2.5 \mathrm{mg} / \mathrm{dl}$

Lactate: $8 \mathrm{mmol} / \mathrm{L}$

Hemoglobin: $10.4 \mathrm{~g} / \mathrm{dl}$

Albumin: 2 gr/dl

Based on the analytical sequence, (Step 1) we begin with the verification of the type of gas obtained, applying the formula as follows:

Type of gas $=\frac{80-\text { MantissapH }}{24(p \mathrm{CO} 2) / \mathrm{HCO}_{-}}$;

Then, replacing values:

Type of gas $=\frac{(80-17)}{(24)(25 \mathrm{mmHg}) / 11 \mathrm{mEq} / \mathrm{L}}=1.15$

Correa Guerrero J, Rico Fontalvo J, Daza Arnedo R, 
A value of 1.15 is obtained, which indicates arterial gas. Therefore, we proceed with the analysis.

Then, (Step 2) the oxygenation degree of the patient is identified with the $\mathrm{Pa} / \mathrm{Fi}$ index as follows:

Oxygenation degree $=\frac{p O 2}{F i O 2}$;

Then, replacing values,

Oxygenation degree $=\frac{84 \mathrm{mmHg}}{0.5}=168 \mathrm{~mm} \mathrm{Hg}$

This result indicates moderate hypoxemia, range $(<200->100)$.

In relation to the acid-base disorder, (Step 3) in this case, the $\mathrm{pH}$ is below 7.35 indicating an acidosis.

(Step 4) The $\mathrm{HCO}_{3}{ }^{-}$is decreased indicating the primary disorder as a metabolic acidosis (see table 2).

(Step 5) Using the formula to assess for compensation would yield a calculated $\mathrm{pCO}_{2}$ as follows (see table 4):

Expected $\mathrm{pCO}_{2}=\left(1.5 \times \mathrm{HCO}_{3}{ }^{-}+8\right) \pm 2$;

Then,

Expected $\mathrm{pCO}_{2}=(1.5 \times 11 \mathrm{mEq} / \mathrm{L}+8) \pm 2=24.5$

$\mathrm{mmHg} \pm 2$;

Therefore, since the calculated $\mathrm{pCO}_{2}(24.5 \mathrm{mmHg})$ is lower than the measured $(25 \mathrm{mmHg})$, the patient has a mixed disorder: metabolic acidosis and respiratory alkalosis.

Then, (Step 6) the $\mathrm{pH}, \mathrm{HCO}_{3}^{-}$and $\mathrm{pCO}_{2}$ are decreased indicating a subacute metabolic acidosis (see table 3 ).

Since it is a metabolic disorder, it is continued (Step

4.1) with the application of the three theories:

(A) Henderson-Hasselbalch: the difference between serum anions and cations is calculated as follows:

$\mathbf{A G}=\left(\operatorname{serum~} \mathrm{Na}^{+}+\operatorname{serum} \mathrm{K}^{+}\right)-\left(\right.$serum $\mathrm{Cl}^{-}+$ serum $\mathrm{HCO}_{3}$ ?)

Then, replacing values,

$\mathrm{AG}=(135 \mathrm{mEq} / \mathrm{L}+3.5 \mathrm{mEq} / \mathrm{L})-(100 \mathrm{mEq} / \mathrm{L}+11$ $\mathrm{mEq} / \mathrm{L})=27.5$

Next, the result must be corrected because this case is a critical patient, through the following formula:

Corrected AG = Calculated AG + 2.5 (Normal albumin - Measured albumin)

Then,

Corrected $\mathrm{AG}=27.5+2.5(4.5 \mathrm{~g} / \mathrm{dl}-2 \mathrm{~g} / \mathrm{dl})=$ 33.75
This result indicates metabolic acidosis with increased AG. In order to verify that there is no other underlying acid-base disorder, the AG delta is calculated as follows:

Gap = Corrected AG - Calculated AG

Replacing values,

Gap $=33.75-27.5=6.25$

Because this value is $>6$ the metabolic acidosis with increased AG is confirmed. Due to the presence of increased lactate $(8 \mathrm{mmol} / \mathrm{L})$ (See table 1) and following the mnemonic

"MUDPILES", it is considered a hyperlactatemic metabolic acidosis secondary to septic shock (see Figure 1.1).

(B) Regarding the calculation of the base excess, the corrected BE equation must be used as follows:

$\mathrm{BE}=\left(\mathrm{HCO}^{3-}-24.4\right)+(8.3 \times$ albumin $\times 0.15)+$ $(0.29 \times$ phosphate $\mathrm{x} 0.32) \times(\mathrm{pH}-7.4)$,

Then, replacing values:

$\mathrm{BE}=(11-24.4 \mathrm{mEq} / \mathrm{L})+(8.3 \times 2 \mathrm{gr} / \mathrm{dl} \times 0.15)+$ $(0.29 \times 2.5 \mathrm{mg} / \mathrm{dl} \times 0.32) \times(7.17-7.4)=-10.9$

Since the BE is -10.9 , the metabolic acidosis is confirmed. In addition, the $\mathrm{pCO}_{2}<35 \mathrm{mmHg}$ is indicating a partially compensated metabolic acidosis (see Figure 1.1).

(C) Peter-Stewart, the decreased $\mathrm{pCO}_{2}$ indicates a respiratory alkalosis. Then, the SID is calculated as follows:

SID $=$ serum $\mathrm{Na}^{+}+\operatorname{serum~} \mathrm{K}^{+}-\operatorname{serum} \mathrm{Cl}$

Then, replacing values,

$\mathrm{SID}=(135 \mathrm{mEq} / \mathrm{L}+3.5 \mathrm{mEq} / \mathrm{L}-100 \mathrm{mEq} / \mathrm{L})=$ $38.5 \mathrm{mEq} / \mathrm{L}$

The result obtained is within the normal range (36 $40 \mathrm{mEq} / \mathrm{L}$ ), and for this reason the $\mathrm{A}_{\text {Tот }}$ must be assess: the decreased albumin indicates a hypoalbuminemic alkalosis and hyperlactatemic organic acidosis (See Figure 1.1).

Finally, (Step 7) the perfusion is assessed as follows: First, the $\mathrm{C}(\mathrm{a}-\mathrm{v}) \mathrm{O}_{2}$ is evaluated as the different between $\mathrm{CaO}_{2}$ and $\mathrm{CvO}_{2}$. The $\mathrm{C}(\mathrm{a}-\mathrm{v}) \mathrm{O}_{2}$ depends on the $\mathrm{SaO}_{2}$, the $\mathrm{SvO}_{2}$ and the hemoglobin, $1 \mathrm{~g}$ of hemoglobin transports $1.34 \mathrm{~mL}$ of $\mathrm{O}_{2}$. The $\mathrm{CaO}_{2}$ and $\mathrm{CvO}_{2}$ are calculated as follows:

$\mathrm{CaO}_{2}=\left(\mathrm{Hb} \times 1.34 \times \mathrm{SaO}_{2}\right)$;

$\mathrm{CaO}_{2}=(10.4 \mathrm{~g} / \mathrm{dl} \times 1.34 \times 0.78)=10.87 \mathrm{vol} \%$

And,

$\mathrm{CvO}_{2}=\left(\mathrm{Hb} \times 1.34 \times \mathrm{SvO}_{2}\right)$; 
$\mathrm{CvO}_{2}=\left(\mathrm{Hb} \times 1.34 \times \mathrm{SvO}_{2}\right)$

$\mathrm{CvO}_{2}=(10.4 \mathrm{~g} / \mathrm{dl} \times 1.34 \times 0.72)=10.03 \mathrm{vol} \%$

Then, the $\mathrm{C}(\mathrm{a}-\mathrm{v}) \mathrm{O}_{2}$ is assessed:

$\mathbf{C}(\mathbf{a}-\mathrm{v}) \mathrm{O}_{2}=\mathbf{C a O}_{2}-\mathbf{C v O}_{2}$

$\mathrm{C}(\mathrm{a}-\mathrm{v}) \mathrm{O}_{2}=10.87 \mathrm{vol} \%-10.03 \mathrm{vol} \%=0.83 \mathrm{vol} \%$

Second, the $\triangle \mathrm{pCO}_{2}$ is calculated as the differrence between venous $\mathrm{pCO}_{2}$ and arterial $\mathrm{pCO}_{2}$ :

$\triangle \mathbf{p C O}_{2}=$ Venous pCO $\mathrm{CO}_{2}$ - Arterial $\mathbf{p C O}_{2}$;

$\triangle \mathrm{pCO}_{2}=26 \mathrm{mmHg}-25 \mathrm{mmHg}=1 \mathrm{mmHg}$

Third, using these parameters: $\mathrm{C}(\mathrm{a}-\mathrm{v}) \mathrm{O}_{2}$ and $\Delta$ $\mathrm{pCO}_{2}$ the perfusion is assessed through the following formula:

Perfusion $=\frac{\Delta p C O 2}{C(a-v) O 2}$

Then, replacing values,

Perfusion $=\frac{1 \mathrm{mmHg}}{0.83 \text { vol\% }}=1.19$

The result obtained indicates hypoperfusion because the value is above 1 (See figure 1)

\section{Conclusions}

The use of a logical and systematic approach is necessary to properly interpret the parameters of the blood gasometry and timely identify the acid-base disorder. In clinical practice, the HendersonHasselbalch theory is a simplified and easy to measure model, the base excess provides an estimate of the magnitude of the acid-base disorder, and the theory of Peter-Stewart allows a more correct interpretation of the metabolic alterations mainly in the complex disorders of the critical patient. The incorporation of the three theories in a diagnostic algorithm facilitates a greater understanding of the pathophysiological mechanisms and allows us to identify a more precise therapeutic objective to correct the underlying disorder in the different clinical contexts of the patient.

\section{Conflicts of Interest}

The authors declared no conflicts.

\section{Funding Statement}

None.

\section{Acknowledgments}

None.

\section{Contribution of the authors}

José Correa Guerrero, Jorge Rico Fontalvo, Rodrigo Daza Arnedo, Emilio Abuabara Franco: Bibliographic search.

Victor Leal Martínez, Nehomar Pájaro Galvis, María Cardona Blanco, María Monterrosa Robles, Jeniffer Palomino Herrera: Writing the Manuscript.

Mauricio Batista Lambis, Isaias Garcerant Campo, Ronald Castro Ahumada, Karen Perales Caballero: Elaboration of tables and algorithm. 
Rev. Colomb. Nefrol. 2020;7(2):85-97, julio-diciembre de 2020 http://www.revistanefrologia.org

http://dx.doi.org/10.22265/acnef.7.2.497

\section{References}

1. Fencl V, Rossing TH. Acid-Base Disorders in Critical Care Medicine. Annu Rev Med. 1989;40(1):17-29. https://dx.doi.org/10.1146/annurev.me.40.020189.000313.

2. Rocktaeschel J, Morimatsu H, Uchino S, Goldsmith D, Poustie S, Story D, et al. Acid-base status of critically ill patients with acute renal failure: analysis based on Stewart-Figge methodology. Crit Care. 2003;7(4):60-6. https://dx.doi.org/10.1186/cc2333.

3. Aristizábal-Salazar RE, Calvo-Torres LF, Valencia-Arango LA, Montoya-Cañon M, Barbosa-Gantiva O, Hincapié-Baena V. Acid-base equilibrium: The best clinical approach. Rev. Colomb. Anestesiol. 2015;43(3):219-24. https://dx.doi.org/10.1016/j.rcae.2015.05.002.

4. Dzierba AL, Abraham P. A practical approach to understanding acid-base abnormalities in critical illness. J Pharm Pract. 2011;24(1):1726. https://dx.doi.org/10.1177/0897190010388153.

5. Palmer BF. Approach to Fluid and Electrolyte Disorders and Acid-Base Problems. Prim Care. 2008;35(2):195-213. https://dx.doi.org/10.1016/j.pop.2008.01.004.

6. Day J, Pandit JJ. Analysis of blood gases and acid-base balance. Surgery. 2011;29(3):107-11. https://dx.doi.org/10.1016/j.mpsur.2010.11.023.

7. Siggard?Andersen O, Fogh?Andersen N. Base excess or buffer base (strong ion difference) as measure of a non?respiratory acid?base disturbance. Acta Anaesthesiol Scand Suppl. 1995;107:123-8. https://dx.doi.org/10.1111/j.1399-6576.1995.tb04346.x.

8. Magder S, Emami A. Practical approach to physical-chemical acid-base management: Stewart at the bedside. Ann Am Thorac Soc. 2015;12(1):111-7. https://dx.doi.org/10.1513/AnnalsATS.201409-426OI.

9. Fores-Novales B, Diez-Fores P, Aguilera-Celorrio LJ. Evaluación del equilibrio ácido-base. Aportaciones del método de Stewart. Rev Esp Anestesiol Reanim. 2016;63(4):212-9. https://dx.doi.org/10.1016/j.redar.2015.04.004.

10. Oliver P, Rodríguez O, Marín JL, Muñoz M, Guillén E, Valcárcel G, et al. Estudio de la oxigenación e interpretación de la gasometría arterial. Documentos de la SEQC. 2015.

11. Williams AJ. ABC of oxygen: assessing and interpreting arterial blood gases and acid-base balance. BMJ. 1998;317(7167):1213-6. https://dx.doi.org/10.1136/bmj.317.7167.1213.

12. Hopkins E, Sanvictores T, Sharma S. Physiology, Acid Base Balance. In: StatPearls Treasure Island (FL): StatPearls Publishing; 2018.

13. Koeppen BM. The kidney and acid-base regulation. Adv Physiol Educ. 2009;33(4):275-81. https://dx.doi.org/10.1152/advan.00054.2009.

14. Prieto-de Paula JM, Franco-Hidalgo S, Mayor-Toranzo E, Palomino-Doza J, Prieto-de Paula JF. Alteraciones del equilibrio ácido-base. Dialisis y Trasplante. 2012;33(1):25-34. https://dx.doi.org/10.1016/j.dialis.2011.06.004.

15. Kamel KS. Diagnostic Use of Base Excess in Acid-Base Disorders. N Engl J Med. 2018;379(5):494-6. https://dx.doi.org/10.1056/ NEJMc1806372.

16. Greenbaum J, Nirmalan M. Acid - base balance?: The traditional approach. Curr Anaesth Crit Care. 2005;16(3):137-42. https://dx.doi.org/10.1016/j.cacc.2005.03.009.

17. Atherton JC. Role of the kidney in acid-base balance. Anaesth Intensive Care Med. 2015;16(6):275-7. https://dx.doi.org/10.1016/J.MPAIC.2015.03.002.

18. Hamilton PK, Morgan NA, Connolly GM, Maxwell AP. Understanding Acid-Base Disorders. Ulster Med J. 2017;86(3):161-6.

19. Paulev PE, Zubieta-Calleja GR. Essentials in the diagnosis of acid-base disorders and their high altitude application. J Physiol Pharmacol. 2005;56(Suppl 4):155-70.

20. Edwards SL. Pathophysiology of acid base balance: the theory practice relationship. Intensive Crit care Nurs. 2008;24(1):28-38. https://dx.doi.org/10.1016/j.iccn.2007.05.003.

21. Kurtz I. Renal Tubular Acidosis: H+/Base and Ammonia Transport Abnormalities and Clinical Syndromes. Adv Chronic Kidney Dis. 2018;25(4):334-50. https://dx.doi.org/10.1053/j.ackd.2018.05.005.

22. Kimura S, Shabsigh M, Morimatsu H. Traditional approach versus Stewart approach for acid-base disorders: Inconsistent evidence. SAGE Open Med. 2018;6:205031211880125. https://dx.doi.org/10.1177/2050312118801255.

96 Acid-base imbalance: a review with proposed unified diagnostic algorithm e2500-5006 Revista Colombiana de Nefrología 
23. Guidet B, Soni N, Rocca G, Kozek S, Vallet B, Annane D, et al. A balanced view of balanced solutions. Crit Care. 2010;14(5):325. https://dx.doi.org/10.1186/cc9230.

24. Sánchez-Díaz JS, Martínez-Rodríguez EA, Méndez-Rubio LP, Peniche-Moguel KG, Huanca-Pacaje JM, López-Guzmán C, et al. Equilibrio ácido-base. Puesta al día. Teoría de Henderson-Hasselbalch. Med Interna Mex. 2016;32(6):646-60.

25. Moe OW, Fuster D. Clinical acid-base pathophysiology: disorders of plasma anion gap. Best Pract Res Clin Endocrinol Metab. 2003;17(4):559-74. https://dx.doi.org/10.1016/s1521-690x(03)00054-x.

26. Figge J, Jabor A, Kazda A, Fencl V. Anion gap and hypoalbuminemia. Crit Care Med. 1998;26(11):1807-10. https://dx.doi.org/10.1097/00003246-199811000-00019.

27. Fencl V, Jabor A, Kazda A, Figge J. Diagnosis of Metabolic Acid - Base Disturbances in Critically Ill Patients. Crit Care Med. 2000;162(6):2246-51. https://dx.doi.org/10.1164/ajrccm.162.6.9904099.

28. Morgan TJ. The meaning of acid-base abnormalities in the intensive care unit: part III - effects of fluid administration. Crit Care. 2005;9(2):204-11. https://dx.doi.org/10.1186/cc2946.

29. Häubi SC, Moreno-Santillán A, de León-Ponce MD, Briones-Vega CG, Meneses-Calderón J, Orenday-Aréchiga ME, et al. Teoría ácidobásico de Stewart, un nuevo paradigma en medicina crítica. Rev Mex Anest. 2006;29(4):240-44.

30. Rastegar A. Clinical utility of Stewart's method in diagnosis and management of acid-base disorders. Clin J Am Soc Nephrol. 2009;4(7):1267-74. https://dx.doi.org/10.2215/CJN.01820309.

31. Kishen R, Honoré PM, Jacobs R, Joannes-Boyau O, De Waele E, De Regt J, et al. Facing acid-base disorders in the third millennium the Stewart approach revisited. Int J Nephrol Renovasc Dis. 2014;7:209-17. https://dx.doi.org/10.2147/IJNRD.S62126.

32. Walley KR. Use of central venous oxygen saturation to guide therapy. Am J Respir Crit Care Med. 2011;184(5):514-20. https://dx.doi.org/10.1164/rccm.201010-1584CI.

33. Hamm LL, Nakhoul N, Hering-Smith KS. Acid-Base Homeostasis. Clin J Am Soc Nephrol. 2015;10(12):2232-42. https://dx.doi.org/10.2215/CJN.07400715.

34. Ospina-Tascón GA, Hernández G, Cecconi M. Understanding the venous-arterial CO2 to arterial-venous O2 content difference ratio. Intensive Care Med. 2016;42(11):1801-4. https://dx.doi.org/10.1007/s00134-016-4233-7.

35. Zakharov S, Navrátil T, Pelclova D. Analysis of serum anion gap and osmolal gap in diagnosis and prognosis of acute methanol poisoning: clinical study in 86 patients. Monatsh Chem. 2015;146(5):787-94. https://dx.doi.org/10.1007/s00706-014-1374-7.

36. Kotrashetti V, Sonawane V, Bainade K, Lal Nath A. Renal Tubular Acidosis-An Unusual Presentation. IOSR J Dent Med Sci. 2015;14(12):65-6. https://dx.doi.org/10.9790/0853-141216566.

37. Choy KW, Wijeratne N, Lu ZX, Doery JC. Harmonisation of Osmolal Gap - Can We Use a Common Formula? Clin Biochem Rev. 2016;37(3):113-9.

38. Sánchez-Sámchez SM, Cachafeiro-Fuciños L, Flores-Cabeza E, García de lo Lorenzo-Mateos A. Alteraciones del metabolismo ácido base: alcalosis. Med - Programa Form Médica Contin Acreditado. 2015;11(79):4759-67. https://dx.doi.org/10.1016/j.med.2015.05.013.

Correa Guerrero J, Rico Fontalvo J, Daza Arnedo R, 